\title{
KINETICS STUDY ON NITRATION OF METHYL RICINOLEATE
}

\author{
Abdullah $^{1,2^{*}}$, Triyono $^{2}$, Wega Trisunaryanti ${ }^{2}$, and Winarto Haryadi ${ }^{2}$ \\ ${ }^{1}$ Department of Chemistry, Faculty of Mathematics and Natural Sciences, Lambung Mangkurat University, \\ Jl. A. Yani Km. 35,8 Banjarbaru, South Kalimantan, Indonesia, 70714 \\ ${ }^{2}$ Department of Chemistry, Faculty of Mathematics and Natural Sciences, Universitas Gadjah Mada, \\ Sekip Utara, Yogyakarta, Indonesia, 55281
}

Received November 7, 2011; Accepted February 7, 2012

\begin{abstract}
Kinetics parameter values of methyl ricinoleate nitration (rate constant, reaction order and the rate of reaction) have been determined. Nitration was carried out with both concentrations of $\mathrm{HNO}_{3}$ and acetic anhydride in excess to the concentration of methyl ricinoleate. Thus, the kinetics parameter value was only affected by the concentration of methyl ricinoleate. Based on kinetic study conducted, it could be concluded that the nitration follows pseudo firstorder, and the reaction rate for methyl ricinoleate with initial concentration of $0.375,0.325$ and $0.250 \mathrm{M}$ were $3.736 \times 10^{-5}, 2.471 \times 10^{-5}$, and $1.724 \times 10^{-5} \mathrm{M} / \mathrm{s}$ respectively, with the rate constant at $29^{\circ} \mathrm{C}$ was $6.667 \times 10^{-4}\left(\mathrm{~s}^{-1}\right)$. Based on evaluation of FTIR spectra could be estimated that the nitration produces compounds containing functional groups of $-\mathrm{NO}_{3}$ and $-\mathrm{NO}_{2}$.
\end{abstract}

Keywords: nitration; methyl ricinoleate; kinetics

\section{ABSTRAK}

Telah ditentukan nilai parameter kinetika dari reaksi nitrasi metil risinolat (konstanta laju, orde dan laju reaksi). Reaksi nitrasi dilakukan dengan $\mathrm{HNO}_{3}$ maupun asam asetat anhidrit dalam konsentrasi berlebih terhadap metil risinolat. Dengan demikian, nilai parameter kinetika dari reaksi nitrasi ini hanya dipengaruhi oleh konsentrasi metil risinolat. Berdasarkan pada hasil pengamatan maka dapat disimpulkan bahwa reaksi nitrasi metil risinolat merupakan reaksi orde 1 semu, konstanta laju reaksi untuk konsentrasi awal sebesar 0,375; 0,325; dan 0,250 M masing-adalah sebesar 3,736 × $10^{-5} ; 2,471 \times 10^{-5}$ dan $1,724 \times 10^{-5} \mathrm{M} /$ detik. Berdasarkan hasil pengamatan spektra FTIR dapat diperkirakan bahwa senyawa hasil nitrasi metil risinolat mengandung gugus fungsi $-\mathrm{NO}_{3}$ dan $-\mathrm{NO}_{2}$.

Kata Kunci: nitrasi; metil risinolat; kinetika

\section{INTRODUCTION}

Nitration is an important reaction in the industrial world. Products of nitration are widely used in industrial paint, explosives and fuel additives [1]. On nitration raw material is reacted with $\mathrm{HNO}_{3}$ and $\mathrm{H}_{2} \mathrm{SO}_{4}$ or acetic anhydride generally [2-3].

Lately, the nitration processes to obtain the additive as a cetane improver on diesel oil are increasingly receiving attention. This is due to the declining quality of crude oil and this impact on the quality of diesel oil which is resulted. One of the nitration compounds that are widely used as an additive is 2-ethylhexyl nitrate (EHN) [4]. This compound is resulted from nitration of propene derivatives at which it was produced from cracking of petroleum and flammable [5]. Therefore, some researchers [5-9] attempt to find another alternative by using triglycerides or fatty acids as raw material. However, although studies on the nitration process of triglycerides or fatty acids and their derivatives have been widely performed, but the study of the kinetics aspect is still very limited.

Determination of kinetics parameter values of a reaction can be performed by conditioning the concentration of one reactant is much larger than the others [10]. This method can also be applied for determination of value of kinetics parameter of nitration, as has been conducted by some researchers [11-13]. Lewis and Moodie [11] reported that the nitration of styrene with the concentration of nitric acid in excess ( $>10$ fold) is a pseudo first-order. This also occurs in the nitration of methanol [12] and toluene [13]. This paper reports that nitration of methyl ricinoleate is also a pseudo first-order.

* Corresponding author. Tel/Fax : +62-511-4772428/4773868

Email address : abdullah.ssi.msi@gmail.com 


\section{EXPERIMENTAL SECTION}

\section{Materials}

Some materials used in this study were methyl ricinoleate $98.7 \%$ (GC), $\mathrm{HNO}_{3} 65 \%$ (Merck), anhydride acetic (Merck), diethyl ether (Merck), anhydrous $\mathrm{Na}_{2} \mathrm{SO}_{4}$ (Merck), universal pH paper (Merck), and distilled water (Physical Chemistry Laboratory UGM).

\section{Instrumentation}

Some of the main instruments used in this study were the three neck distillation flask (Pyrex), the cooler of ball type (Pyrex), magnetic stirrer (Stuart SB 163), water bath, separating funnel (Pyrex), and gas chromatography (GC Hawlett Pacard 5890 seri II).

\section{Procedure}

\section{Mol ratio of $\mathrm{HNO}_{3}$ to methyl ricinoleate (MR) determination}

The experiment was intended to determine the optimum mole ratio of $\mathrm{HNO}_{3}$ on methyl ricinoleate. The optimum mole ratio can be determined from the concentration of residual of MR which was observed in the reaction mixture by gas chromatography (GC). The nitration was carried out at room temperature with reaction time of $25 \mathrm{~min}$. Here the number of moles of each reactant and the mole ratio of $\mathrm{HNO}_{3}$ and $\mathrm{MR}$ were used in this experiment.

\section{Methyl ricinoleate nitration}

In the nitration process, initially $\mathrm{HNO}_{3}$ was added in the flask, and then followed by addition of acetic anhydride. Furthermore, a magnetic stirrer was operated slowly (200 rpm), until the temperature in the distillation flask becomes constant. After the temperature constant, then methyl ricinoleate was added into a flask quickly. After the reaction run for $\mathrm{t}$ min, the sample was taken for purification process.

Purification was carried out by adding the sample in $200 \mathrm{~mL}$ of ice water, and then the mixture was put in a separating funnel $(500 \mathrm{~mL})$, and followed by addition of diethyl ether $(20 \mathrm{~mL})$. Furthermore, the upper layer was washed using $50 \mathrm{~mL}$ of distilled water several times until the washing water become neutral. The upper layer was dried with anhydrous $\mathrm{Na}_{2} \mathrm{SO}_{4}$, and then allowed to stand for $24 \mathrm{~h}$. The mixture was filtered and the diethyl ether layer was evaporated by heating at a temperature of $80{ }^{\circ} \mathrm{C}$ for about $30 \mathrm{~min}$. Evaporation was stopped after a constant weight was obtained, then analyzed by GC and FTIR.
Table 1. Mole ratio of $\mathrm{HNO}_{3}$ to methylricinoleate (MR)

\begin{tabular}{|c|c|c|c|}
\hline \multirow[b]{2}{*}{ No. } & \multicolumn{2}{|c|}{ Reactant } & \multirow[b]{2}{*}{$\begin{array}{c}\text { Mole ratio } \\
\left(\mathrm{HNO}_{3}: \mathrm{MR}\right)\end{array}$} \\
\hline & $\begin{array}{c}\mathrm{HNO}_{3} \\
\text { (mole; } \mathrm{mL} \text { ) }\end{array}$ & $\begin{array}{c}\mathrm{MR} \\
\text { (mole; } \mathrm{mL})\end{array}$ & \\
\hline 1. & $0.010 ; 0.7$ & $0.010 ; 3.3$ & $1: 1$ \\
\hline 2. & $0.020 ; 1.4$ & $0.004 ; 1.3$ & $5: 1$ \\
\hline 3. & $0.040 ; 2.8$ & $0.004 ; 1.3$ & $10: 1$ \\
\hline 4. & $0.045 ; 3.0$ & $0.003 ; 1.0$ & $15: 1$ \\
\hline 5. & $0.040 ; 2.8$ & $0.002 ; 0.6$ & $20: 1$ \\
\hline 6. & $0.100 ; 7.0$ & $0.004 ; 1.3$ & $25: 1$ \\
\hline
\end{tabular}

Table 2. Variation of mole and volume of MR, AA and $\mathrm{HNO}_{3}$

\begin{tabular}{ccc}
\hline $\mathrm{HNO}_{3}$ (mole; $\left.\mathrm{mL}\right)$ & AA (mole; $\mathrm{mL})$ & $\mathrm{MR}($ mole; $\mathrm{mL})$ \\
\hline $0.270 ; 18$ & $0.270 ; 24$ & $0.018 ; 6$ \\
$0.270 ; 18$ & $0.270 ; 24$ & $0.015 ; 5$ \\
$0.270 ; 18$ & $0.270 ; 24$ & $0.012 ; 4$ \\
\hline
\end{tabular}

Note: Total volume of reactant was $48 \mathrm{~mL}$. Control of total volume was carried out with $\mathrm{H}_{2} \mathrm{O}$ addition.

Determination of kinetics parameter values of methyl ricinoleate nitration

Determination of kinetics parameter values was performed by varying the number of moles of methyl ricinoleate (MR), while the number of moles both $\mathrm{HNO}_{3}$ and acetic anhydride (AA) were not varied. The nitration was conducted at room temperature with the variation of reaction time $(5,11,17,23$ and $29 \mathrm{~min})$.

\section{RESULT AND DISCUSSION}

\section{The optimum mole ratio of $\mathrm{HNO}_{3}$ to $\mathrm{MR}$}

$\mathrm{HNO}_{3}$ is a polar compound, and methyl ricinoleate (MR) has a relatively low polarity. Therefore $\mathrm{HNO}_{3}$ and methyl ricinoleate can not mix well in any ratio. While this reaction required a high homogeneity of mixture, so the reaction can be run optimally. Therefore, it was necessary to vary the ratio of moles of $\mathrm{HNO}_{3}$ to the acetic anhydride. The optimum mole ratio was observed from the low concentration of the residual MR determined by GC. Fig. 1 showed the relationship of concentration of residual MR to different mole ratio.

Based on Fig. 1 could be shown that the optimum mole ratio was at range $15: 1$ to $20: 1$. Therefore, the nitration then was performed on those ratios. For the area ratio of $1: 1,5: 1$ and $10: 1$, the concentrations of residual methyl ricinoleate in the reaction mixture were still high. This was caused by a mixed system that had not been homogeny. As for the ratio of 25:1 was caused by low concentrations of methyl ricinoleate in the mixture. 


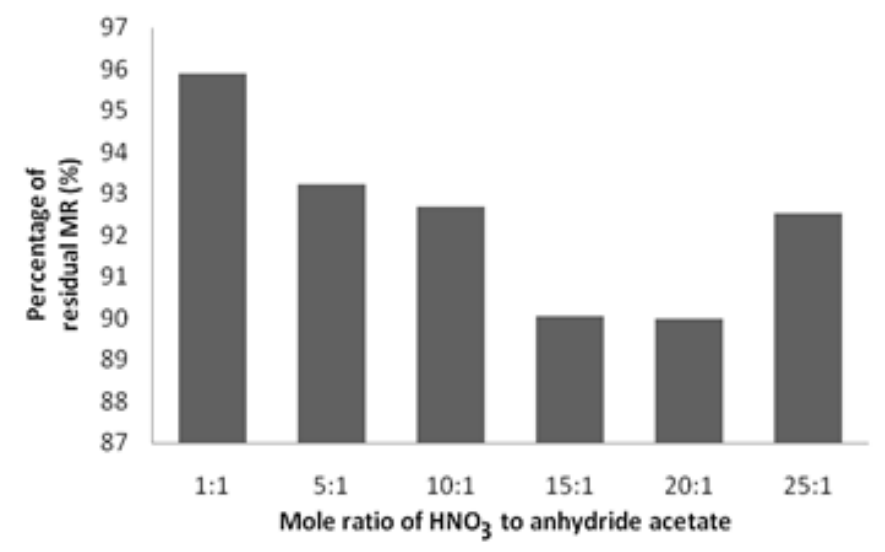

Fig 1. Plot of percentage of residual concentration of MR versus mole ratio of $\mathrm{HNO}_{3}$ to $\mathrm{MR}$

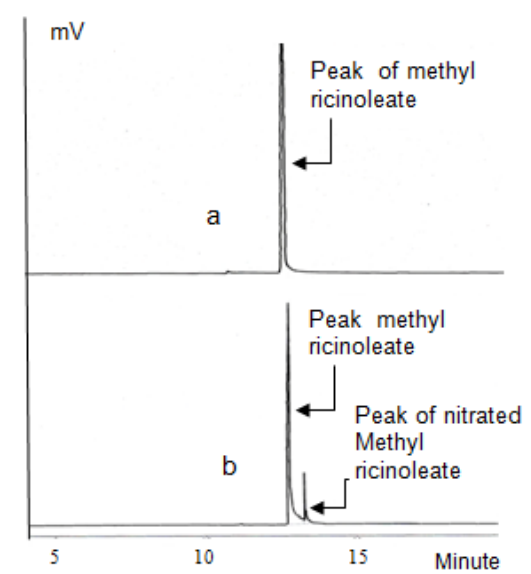

Fig 2. Chromatogram of methyl ricinoleate before nitration (a) and after nitration (b)

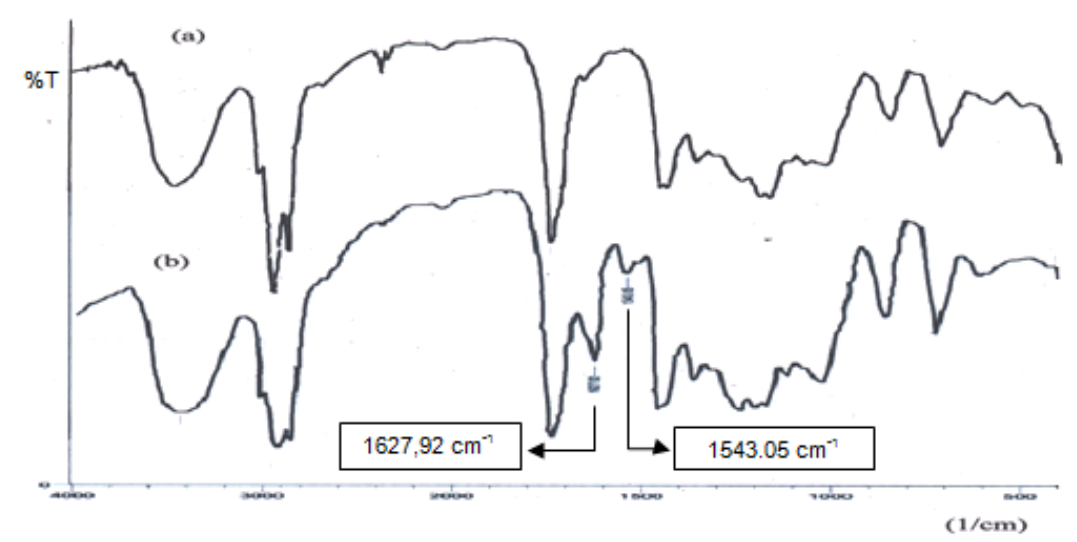

Fig 3. FTIR spectra of methyl ricinoleate before nitration (a) and after nitration for $29 \mathrm{~min}$ (b)

Table 3. Interpretation of bonds and functional groups of the methyl ricinoleate

\begin{tabular}{cccc}
\hline No. & Wavenumber $(1 / \mathrm{cm})$ & Bond (kind of vibration) & Functional group \\
\hline 1. & 3421.78 & $\mathrm{O}-\mathrm{H}$ (stretching) & Alcohol \\
& 1246.04 & $\mathrm{C}-\mathrm{O}$ (stretching) & \\
2. & 3009.00 & $\mathrm{C}-\mathrm{H}$ (stretching) & Alkene \\
& 856.41 & $\mathrm{C}-\mathrm{H}$ (bending) & Alkyl \\
3. & 2927.99 & $\mathrm{C}-\mathrm{H}$ (stretching, antisymetric) & Alkyl \\
& 2854.70 & $\mathrm{C}-\mathrm{H}$ (stretching, symmetric) & Methylene \\
& $1462.07 ; 1438.92$ and & $\mathrm{C}-\mathrm{CH}_{2}$ (stretching) & Methyl \\
& 1361.77 & $-\mathrm{CH}_{3}$ (stretching) & Long chain alkyl \\
4. & 725.25 & $\mathrm{C}-\mathrm{H}$ (stretching & Ester \\
5. & 1739.82 & $\mathrm{C}=\mathrm{O}$ (stretching) & Ether \\
\hline
\end{tabular}

\section{Nitration of methyl ricinoleate and the results of GC and FTIR analysis}

Firstly, nitration was performed by mixing of $\mathrm{HNO}_{3}$ with acetic anhydride. The mixing was intended to get the nitronium ion $\left(\mathrm{NO}_{2}{ }^{+}\right)$that act as electrophiles. Nitronium ion was formed as a result of interaction between $\mathrm{HNO}_{3}$ with acetic anhydride through the following mechanisms.
$\left(\mathrm{CH}_{3} \mathrm{CO}\right)_{2} \mathrm{O}+\mathrm{H}_{2} \mathrm{O} \rightleftharpoons 2 \mathrm{CH}_{3} \mathrm{COOH}$

$2 \mathrm{CH}_{3} \mathrm{COOH}+2 \mathrm{HNO}_{3} \rightleftharpoons 2 \mathrm{CH}_{3} \mathrm{COO}^{-}+2 \mathrm{NO}_{2}{ }^{+}+2 \mathrm{H}_{2} \mathrm{O}$

On the nitration process, nitronium ion reacted with methyl ricinoleate to form a new compound. Observation on the new compound was performed by gas chromatography (GC). Fig. 2 showed chromatograms of methyl ricinoleate before nitration (a) and after nitration (b). 
Table 4. Concentration of MR after reacted for $t \mathrm{~min}$

\begin{tabular}{cccc}
\hline$\%(\mathrm{GC})$ & $\mathrm{MR}$ & $\mathrm{Ln} \mathrm{MR}$ & $\mathrm{t}(\mathrm{min})$ \\
\hline & Seri 1 $\left([\mathrm{MR}]_{0}=\right.$ & $0.375 \mathrm{M}])$ \\
\hline 97.4191 & 0.365 & -1.0079 & 5 \\
93.2910 & 0.350 & -1.0498 & 11 \\
92.3294 & 0.346 & -1.0613 & 17 \\
90.3996 & 0.339 & -1.0818 & 23 \\
86.3331 & 0.324 & -1.1270 & 29 \\
\hline \multicolumn{4}{c}{ Seri 2 $\left.\left([\mathrm{MR}]_{0}=0.312 \mathrm{M}\right]\right)$} \\
\hline 98.5290 & 0.308 & -1.1780 & 5 \\
96.8851 & 0.303 & -1.1948 & 11 \\
91.3256 & 0.285 & -1.2539 & 17 \\
90.1611 & 0.282 & -1.2667 & 23 \\
88.2172 & 0.276 & -1.2885 & 29 \\
\hline \multicolumn{5}{c}{ Seri 3 $\left.\left([\mathrm{MR}]_{0}=0.250 \mathrm{M}\right]\right)$} \\
\hline 96.9155 & 0.242 & -1.4176 & 5 \\
96.2889 & 0.241 & -1.4241 & 11 \\
92.5406 & 0.231 & -1.4638 & 17 \\
90.3648 & 0.226 & -1.4876 & 23 \\
88.6936 & 0.222 & -1.5063 & 29 \\
\hline
\end{tabular}

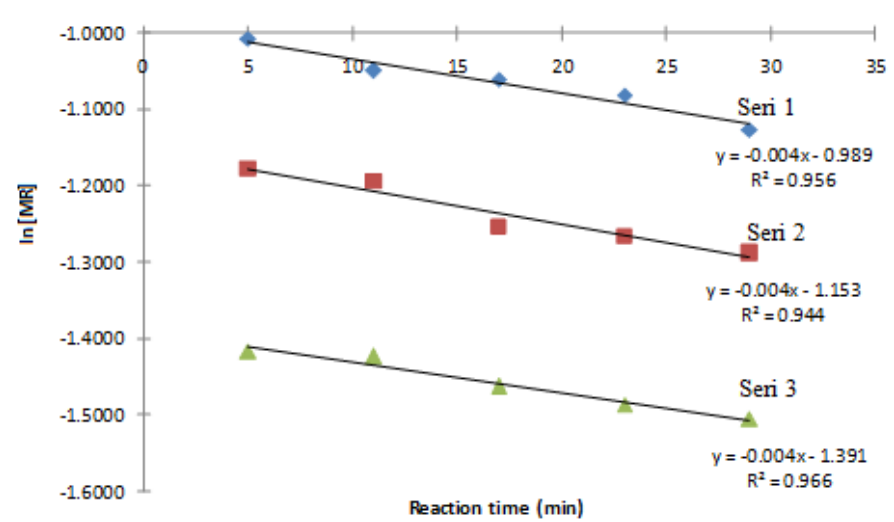

Fig 4. Plot of In MR versus reaction time

Fig. 2a showed that peak of methyl ricinoleate appeared at a retention time of about $12.6 \mathrm{~min}$, while the peak of nitrated methyl ricinoleate appeared at $13.0 \mathrm{~min}$. The concentration of nitrated methyl ricinoleate was 11.42 (\%, GC) for nitration 29 min (Fig. 2b). Analysis of the products of nitration also be performed with FTIR and compared to the original compound (methyl ricinoleate).

Interpretation of the spectra of methyl ricinoleate (Fig. 3a) in determining the type of bonding and functional groups was listed in Table 3.

Fig. 3b showed two new spectrums that appeared at the wavenumber of 1627.92 and $1543.05 \mathrm{~cm}^{-1}$. The existence of $-\mathrm{NO}_{3}$ group was marked by a sharp absorption spectrum in the region $1650-1500 \mathrm{~cm}^{-1}$ [14], while the $-\mathrm{NO}_{2}$ group was marked by a sharp spectrum at region of $1550-1372 \mathrm{~cm}^{-1}$ and a spectrum with moderate intensity in the region of $1390-1300 \mathrm{~cm}^{-1}$. According to Suppes at al. [5], the formation of nitrate compound (-NO $\mathrm{NO}_{3}$ group) was marked by spectrum at 1650, 1282 and $854\left(\mathrm{~cm}^{-1}\right)$, meanwhile for nitro compounds $\left(-\mathrm{NO}_{2}\right.$ group) were characterized by the wavenumber spectrum at 1553 and $1375 \mathrm{~cm}^{-1}$. Based on this information could be estimated that compound which was resulted from nitration of methyl ricinoleate was a molecules containing nitrate and nitro groups.

\section{The rate constant, the reaction order and the rate of reaction}

According to House [16], on the reaction of $A+B$ $+C \rightarrow$ Product, at which $[A]$ and $[B]$ were set such that both were excess to $[C]$, then $[A]$ and $[B]$ will not change significantly to change in $[\mathrm{C}]$. Therefore, the change of $[M R]$ to the initial concentration $\left([M R]_{0}\right)$ could be expressed as:

$\mathrm{r}=\frac{\mathrm{dx}}{\mathrm{dt}}=\mathrm{k}\left[\mathrm{HNO}_{3}\right]^{\mathrm{v}}[\mathrm{AA}]^{\mathrm{w}}\left([\mathrm{MR}]_{0}-x\right)^{\mathrm{q}}$

Because the concentration of $\mathrm{HNO}_{3}$ and $\mathrm{AA}$ can be considered constant, then equation 1 turns into equation 2 and 3.

$\mathrm{r}=\mathrm{k}^{\prime}\left([\mathrm{MR}]_{0}-x\right)^{\mathrm{q}}$ wherein $\mathrm{k}^{\prime}=\mathrm{k}\left[\mathrm{HNO}_{3}\right]^{\vee}[\mathrm{AA}]^{\mathrm{w}}$

Later in the determination of the reaction order (q), if the reaction order equal to 1 , then through the relationship $d[M R] /[M R]=-k d t$, by integrating the equation would be obtained:

$\ln [\mathrm{MR}]=\ln [\mathrm{MR}]_{0}-\mathrm{kt}$

From equation 3 , then by plotting In [MR] versus $t$ would be obtained a straight line, at which slop equal to $-k$ for each series of experiment.

Table 4 showed the concentration of residual methyl ricinoleate ([MR]) in the mixture after reacted for $\mathrm{t}$ min, where the concentration of MR data was obtained by GC. Percentage values in the GC data was multiplied by $[M R]_{0}$, so that $[M R]$ after the reaction could be determined. Furthermore, the data [MR] was converted into In [MR], then used in the plotting of the graph in Fig. 4.

Fig. 4 showed that the resulting line had a high linearity. This was evidenced by the value of $R^{2}$ almost close to 1 . Thus the initial assumption by assigning values to the MR order reaction equal to 1 was correct. In this case the reaction order of MR was said to be pseudo first order. Then from the equation of the line in Fig. 4 could be seen that the slope was also the value of $-\mathrm{k}$ (average) was equal $4 \times 10^{-3}$, so that the rate constant value $(\mathrm{k})$ was equal to $4 \times 10^{-3}\left(\mathrm{~min}^{-1}\right)$ or equal to $6.667 \times 10^{-4}\left(\mathrm{~s}^{-1}\right)$.

On series different initial concentrations, the change concentration of MR with time of reaction were monitored. So by plotting [MR] versus time a reaction rate was evaluated from slope. The slope was obtained by drawing a tangent curve starting from $\mathrm{t}=0$. 


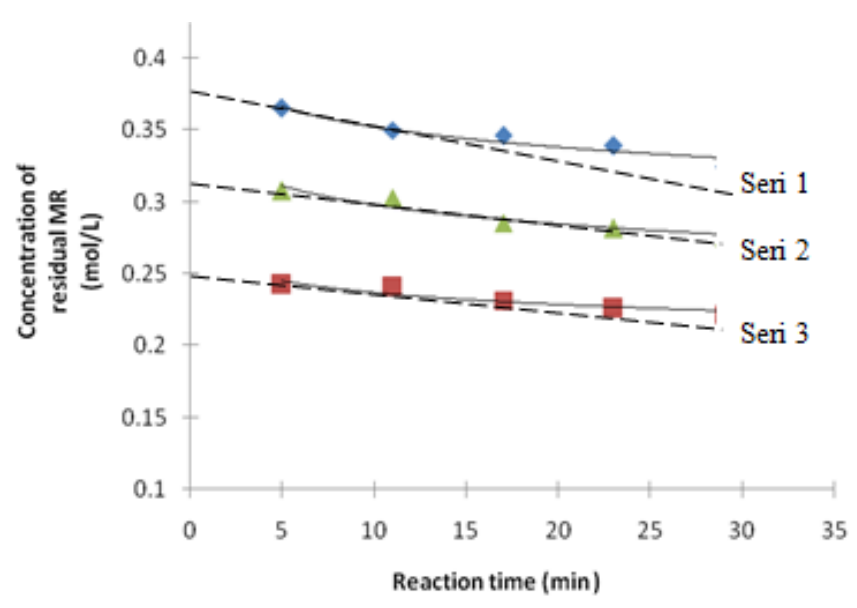

Fig 5. Plot of residual concentration of MR versus time of reaction

Based on Fig. 5, and then carried out the calculation as follows:

$$
\begin{aligned}
\text { Rate }_{\text {seri } 1} & =\frac{(0.310-0.375)}{(29-0)} \\
& =-0.00224138 \mathrm{M} / \mathrm{min}=-3.736 \times 10^{-5} \mathrm{M} / \mathrm{s} \\
\text { Rate }_{\text {ser } 2} & =\frac{(0.270-0.312)}{(29-0)} \\
& =-0.00148276 \mathrm{M} / \mathrm{min}=-2.471 \times 10^{-5} \mathrm{M} / \mathrm{s} \\
\text { Rate }_{\text {seri } 3} & =\frac{(0.220-0.250)}{(29-0)} \\
& =-0.00103448 \mathrm{M} / \mathrm{min}=-1.724 \times 10^{-5} \mathrm{M} / \mathrm{s}
\end{aligned}
$$

Thus the reaction rate for each series of experiments was $3.736 \times 10^{-5} \mathrm{M} / \mathrm{s}, 2.471 \times 10^{-5} \mathrm{M} / \mathrm{s}$, and $1.724 \times 10^{-5} \mathrm{M} / \mathrm{s}$.

\section{CONCLUSION}

Based on kinetic studies conducted, it could be concluded that nitration of methyl ricinoleate follows pseudo first-order reaction, the reaction rate for each initial methyl ricinoleate concentration of $0.375,0.325$ and $0.250 \mathrm{M}$ was $3.736 \times 10^{-5}, 2.471 \times 10^{-5}$ and $1.724 \times 10^{-5} \mathrm{M} / \mathrm{s}$, meanwhile reaction rate constant at $29{ }^{\circ} \mathrm{C}$ of $6.667 \times 10^{-4}\left(\mathrm{~s}^{-1}\right)$. Identification with FTIR, it could be estimated that the results of nitration was a compound containing $-\mathrm{NO}_{3}$ and $-\mathrm{NO}_{2}$ groups.

\section{ACKNOWLEDGEMENT}

Acknowledgements to Staff of Physical Chemistry who prepared the instruments and chemicals for this research.

\section{REFERENCES}

1. Ali, M.F., Ali, B.M.E., and Speight, J.G., 2005, Handbook of Industrial Chemistry, McGraw-Hill Companies, New York.

2. Olah, G.A., Narang, S.C., and Olah, J.A., 1981, Proc. Natl. Acad. Sci. USA, 78, 6, 3298-3300.

3. Odle, R.R., 1990, Nitration Reaction with Acid Anhydride Promoters, US Paten, 4, 921, 970.

4. Solano-Serena, F., Nicolau, E., Favreau, G., Jouanneau, Y., and Marchal, R., 2007, Biodegradation, 20, 1, 85-95.

5. Suppes, G.J., Heppert, J.A., and Mason, M.H.JR., 2001, Process for Producing Cetane Improvers from Triglycerides, US Patent, 2001/0037598 A1.

6. Poirier, M-A., Steere, D.E., and Krogh, J.A., 1995, Cetane Improver Compositions Comprising Nitrated Fatty Acid Derivatives, US Patent, 5, 454, 842.

7. Adnan, R., 2002, Synthesis of Cetane Improver Additive from Palm Oil by Method of Nitration through Initial Reaction Using a Grignard Reagent, Thesis, Faculty of Chemical Engineering UI, Jakarta.

8. Canoira, L., Alcantara, L., Torcal, S., Tsiouvaras, N., Lois, E., and Korres, D.M., 2007, Fuel, 86, 7-8, 965-971.

9. Rabello, C.R, Siqueira, B.G., and Demenezez, R.B., 2009, Method for Production of Cetane-Index Improvement Additive for Diesel Oil, US Patent, 2009/0100749 A1.

10. Houle, C.R., and Malins, D.C., 1967, Nitrated Fatty Acid Esters, US Patent, 3, 305, 567.

11. Lewis, R.J. and Modie, R.B., 1997, The Nitration of Styrenes by Nitric Acid in Dichlorometane, $J$. Chem. Soc. Perkin Trans, 2, 3, 563-567.

12. Iraci, L.T, Riffel, B.G., Robinson, C.B., Michelsen, R.R., and Stephenson, R.M., 2007, J. Atmos. Chem., 58, 253-266.

13. Sreedhar, I., Reddy, K.S.K., and Raghavan, K.V., 2009, Int. J. Chem. Eng. Res., 1, 2, 89-102.

14. Wade, Jr. L.G., 2006, Organic Chemistry, $6^{\text {th }}$ ed., Pearson Education Inc., USA.

15. Pavia, D.L., Lampman, G.M., Kriz, G.S., and Vyvyan, J.R., 2009, Introduction to Spectroscopy, $4^{\text {th }}$ ed., Brooks/Cole Cencage Learning, Australia.

16. House, J.E., 2007, Priciples of Chemical Kinetics, $2^{\text {nd }}$ ed., Elsevier, USA. 